\title{
THE
}

2016

\section{Efficiency of Viable Groundwater Management Policies}

Todd Guilfoos

University of Rhode Island, guilfoos@uri.edu

Neha Khanna

Jeffrey M. Peterson

Follow this and additional works at: https://digitalcommons.uri.edu/enre_facpubs

The University of Rhode Island Faculty have made this article openly available.

Please let us know how Open Access to this research benefits you.

This is a pre-publication author manuscript of the final, published article.

Terms of Use

This article is made available under the terms and conditions applicable towards Open Access Policy Articles, as set forth in our Terms of Use.

\section{Citation/Publisher Attribution}

Guilfoos, T., Khanna, N., \& Peterson, J. M. (2016). Efficiency of viable groundwater management policies. Land Economics, 92(4), 618-640. https://doi.org/10.3368/le.92.4.618

Available at: https://doi.org/10.3368/le.92.4.618

This Article is brought to you for free and open access by the Environmental and Natural Resource Economics at DigitalCommons@URI. It has been accepted for inclusion in Environmental and Natural Resource Economics Faculty Publications by an authorized administrator of DigitalCommons@URI. For more information, please contact digitalcommons-group@uri.edu. 
Title Page:

Efficiency of Viable Groundwater Management Policies

Todd Guilfoos $^{\mathrm{a}}$, Neha Khanna ${ }^{\mathrm{b}}$, Jeffrey M. Peterson ${ }^{\mathrm{c}}$

Corresponding Author:

Todd Guilfoos

Department of Environmental and Natural Resource Economics

University of Rhode Island

219 Coastal Institute

1 Greenhouse Road, Kingston, RI 02881

Phone: 401-874-4398; Email: guilfoos@mail.uri.edu

${ }^{a}$ Department of Environmental and Natural Resource Economics, University of Rhode Island, 219 Coastal Institute, 1 Greenhouse Road, Kingston, RI 02881

${ }^{\mathrm{b}}$ Department of Economics and Environmental Studies Program, LT 1004, P.O. Box 6000, Binghamton University, Binghamton, NY 13902-6000

${ }^{\mathrm{c}}$ Water Resources Center and Department of Applied Economics, University of Minnesota, 173 McNeal Hall, 1985 Buford Avenue, St. Paul, MN 55108 
5 We investigate the relative performance of simple groundwater policies in a spatially detailed aquifer and reveal the distribution of net benefits from those policies. Groundwater policy is

7 plagued with a high level of complexity in achieving the first best outcome, which may be costly

8 and politically infeasible to adopt. We parameterize a 8,457 cell spatially detailed model of the

9 Northwest Kansas section of the Ogallala Aquifer and find that simple pricing, quantity, and 10 water market policies perform poorly but can be improved upon by localized policies that are 11 more efficient and garner more popular support.

13 Key words: Hydraulic Conductivity, Common Pool Resource, Groundwater Management, Water 14 Markets, Ogallala

15 JEL codes: C63, D62, D90, Q10, Q15, Q25

Groundwater represents roughly $96 \%$ of the world's unfrozen fresh water resources and approximately $60 \%$ of the groundwater extracted is used for agriculture (Jousma and Roelofsen 2004). Depletion of these resources is of great concern throughout the world, especially where extraction consistently outstrips natural recharge. For example, there are many areas throughout

21 the world where aquifers face depletion such as the Ogallala aquifer, the Central Valley of 22 California in the United States, the North China Plains Aquifer (Qui 2010), or a series of shallow 23 aquifers, including the Neogene and Dammam aquifers in eastern Saudi Arabia. These aquifers 24 are in danger mainly because the irrigation needs in these areas are much larger than what can be 25 supported sustainably (Gleeson 2012). The cumulative extraction of groundwater for irrigation 
has resulted in considerable decrease in land values as depletion reduces remaining stocks and

27 increases extraction costs (Hornbeck and Keskin 2011). However, spatial variation is also

28 important; while total water supplies in a region or country may be larger than the aggregate

29 demand, areas with concentrated irrigation may run out of water because groundwater takes time to flow through the ground due to finite hydraulic conductivity. There are of course other drivers

31 of groundwater policy that could be important as well, such as stream flow considerations, ecosystem services, or transboundary issues where groundwater traverses political boundaries.

Regardless of the specific context or drivers of local groundwater policies, groundwater management can be complicated and, a priori, the net benefits of simple management regimes in a complex aquifer are unclear. Many previous studies have found a small net benefit overall

36 from optimal management, but these models were not designed to assess the distribution of 37 gains. Even if the net benefit is small on average over a large aquifer, there may be large 38 gains/losses for farmers and other water users in certain locations. Such variations are policy relevant because they provide insights on which policy instruments would be politically feasible and how the net benefit would be distributed. To satisfy the first best management policy, water conservation may need to be regulated at a field level and would change season to season to

42 incorporate groundwater flows, precipitation, and water demand at a field level. While this 43 detailed policy may retrieve the maximum net benefit from management it may require a high 44 level of monitoring and enforcement which most likely renders it unattractive due to the high 45 economic cost as well as political infeasibility. These complications generally make simpler 46 policies, such as uniform taxes, quantity restrictions, or simple markets more attractive to water 47 managers and policy makers. Our goal in this paper is to investigate how well simple policies, 48 in particular, policies that are spatially uniform, perform in terms of increasing net benefits. Can 
49 simple policies that ignore the underlying hydrogeology of the aquifer deliver substantial net

benefits and what is the distribution of these net benefits across the farmers on the aquifer?

One highly touted policy is a water market where permit holders can trade for rights to groundwater extraction. Several countries including Australia, Chile, India, and the United States have instituted various forms of water markets (Bauer 1997, Mukherji 2004, Brennan 2006, Brown 2006, Hadjigeorgalis 2009, Goemans and Prichett 2014). Policy experts have also called for expansion of water markets as an effective tool to deal with spatial inefficiencies in reducing the costs of water restrictions (Thompson et al. 2009). Several studies have analyzed possible gains from water markets in general, pricing in such markets, and practical concerns of adopting a market (Colby et al. 1993, Murphy et al. 2000, Weinberg 2002, Didri and Khanna 2005, Palazzo and Brozovic 2014, Brozovic and Young 2014) as well as the interaction of water markets and water quality (Weinberg et al. 1993). Carey and Zilberman (2002) evaluate technology choice, crop choice, and capital investment with water markets. Palazzo and Brozovic (2014) find that groundwater trading could significantly reduce the abatement costs of farmers and therefore provide cost savings, but that the cost savings can vary greatly by location when trading restrictions are enforced. Others highlight the important struggles and design considerations when implementing groundwater markets, such as strong and consistent institutions across basins (Wheeler et al. 2014).

We are interested in what might be called "second best" groundwater management policies, in the sense that they are simple instruments to implement while yielding a higher net benefit than doing nothing. The nomenclature may be slightly misleading as we do not actually identify the second best policy; we assess simple policies in the absence of the first best, as measured by the present value net benefits to users compared to the status quo. ${ }^{1}$ In particular, we 
72 determine the present value net benefits compared to the status quo from spatially uniform price

73 and quantity restrictions. We also investigate how static water markets perform over the life of

74 the aquifer. Models analyzing the benefits of water markets (Palazzo and Brozovic 2014)

75 implicitly assume that exhaustion is not a primary concern therefore there are only benefits from

76 water markets in a static framework. But simple water markets that do not specifically account

77 for local depletion could be damaging over time as they may exacerbate depletion of a

78 productive well. Other studies have examined pricing policies and efficiency; Tsur and Dinar

79 (1997) review different pricing policies and water markets and consider their implementation

80 costs across many countries. Sekhri (2011) studies the effect of public provision of groundwater

81 and finds that it may conserve water in Northern India. Burness and Brill (2001) investigate

82 second best policy measures in Curry County, New Mexico, and find significant differences

83 between the first best and second best policies, but also find overall net benefits to be small.

84 Like many other studies, Burness and Brill (2001) use a 'bathtub' model in which the aquifer is

85 modeled as a single cell and the height of water is uniform across the entire aquifer, making

86 lateral water movement instantaneous. Thus, when a withdrawal of water occurs water decreases

87 in height throughout the aquifer in a uniform fashion, as it would when draining a bathtub.

88 Another implicit assumption in the bathtub model is that land quality and farmers' technology is

89 uniform, so that the surplus earned from extraction is equivalent to that of a single representative

90 farmer. Thus, these models do not assess the role of spatial heterogeneity nor the distribution of

91 gains and losses across farmers.

92 We assess the ability of simple spatially uniform groundwater management policies --

93 policies that may be appealing in a realistic setting due to their simple design -- to yield net

94 benefits in an area where groundwater management is driven by aquifer depletion. We use a 
multi-cell model of the aquifer in which groundwater flows from cell to cell, consistent with the hydrologic properties of the aquifer. By explicitly modeling the lateral flow of water between

97 cells in the aquifer we provide a more accurate representation of local water scarcity and water

98 depths that individual farmers face. This distinction is important as the size and distribution of net benefits can vary based on location or heterogeneity in demand for water as seen in Guilfoos et al. (2013).

Others before us have investigated the gradual movement of groundwater and its 102 implications for policy (Zimmerman 2001, Brozovic et al. 2010, Savage and Brozovic 2011, 103 Athanassoglou et al. 2012, Suter et al. 2012, Kuwayama and Brozovic 2013) and there is a 104 growing trend in the literature to incorporate lateral water flows into economic analyses. The 105 lateral flow of water has been considered, for example, in the context of trading ratios in water 106 markets (Palazzo and Brozovic 2014), land-surface zoning (Adams and Foster 1992) and well 107 spacing requirements (Johnson 1982). Mulligan et al. (2014) also use a similar modeling 108 approach to our paper but ours is distinct in three important ways. We construct demand for 109 groundwater in which costs depend on the extraction rate and level; they use crop choice where 110 costs do not vary with extraction. We explicitly model extraction costs as an important element 111 of the changing groundwater height. They restrict their analysis to a flat tax and uniform quota-112 we include these policies but also consider variable taxes, water markets, and local management 113 schemes. We also differentiate our contribution by evaluating the drivers of the individual 114 benefits from these policies and look at the distribution of net benefits. We focus on determining 115 the spatial and therefore, across farmer, distribution of net benefits from simple groundwater 116 management strategies in the presence of low hydraulic conductivity. 
The specific policies that we investigate are: 1) a flat tax, which is uniform over space 118 (and so also farmers) and time; 2) a temporally variable tax, which is uniform over space and 119 farmers but varies over time; 3) quantity restrictions, which are percentage reductions that are 120 uniform over space and time; 4) static water markets, which allocate water across space but not 121 across time; and $\left.^{2} 5\right)$ local area management where a smaller area within the aquifer is managed 122 with simple pricing and quantity policies. In each case, we focus on the optimal policy which 123 achieves the highest net benefit possible given constraints on the resolution of the policy tool, 124 such as constraining the policy to be uniform across the aquifer. To simplify comparison, we 125 assume that the tax revenues raised under the two tax policies are returned to the farmers via a 126 non-distortionary lump sum transfer. The water markets are overlaid on the pricing and quantity 127 policy tools; for example we use the optimal trajectory of total water extracted under the flat tax 128 to define the amount of permits distributed in each period in the water market and without any 129 additional restrictions due to local depletion. We assess the relative effectiveness of these 130 policies by calibrating our model to the Groundwater Management District 4 in Northwest 131 Kansas, which overlays the Ogallala Aquifer and which is subject to concerns of depletion (see 132 figure 1).

We choose these policies because the differentials between them identify factors that 134 contribute to the distribution of net benefits across different farmers and their relevance to 135 groundwater management practices. For example, the difference between the optimal flat tax 136 and the optimal variable tax identifies the degree to which an improved inter-temporal allocation 137 adds to the net benefits from groundwater management. The difference between an optimal flat 138 tax and the water market using the same quantities identifies the additional net benefits when 139 water is allocated to areas with the highest marginal value across space but not across time. 
140 Markets will capture more net benefits than a uniform policy in a given period, because a 141 uniform tax raises the already heterogeneous cost of pumping so does not equalize marginal 142 returns while trading allows for spatially differentiated water use if low-value irrigators sell to 143 high-value irrigators. An alternative to markets, which may be more feasible, is to have 144 spatially non-uniform policies such as quantity restrictions tied to local hydrologic conditions. 145 This local management paradigm underlies the Kansas law that enables the creation of Local 146 Enhanced Management Areas (LEMAs) which are smaller geographical units of management 147 voluntarily formed and managed by the farmers residing in the area.

148 Our primary contributions to the literature are twofold. First, we determine the spatial 149 distribution of net benefits across individual farmers from the specific policies we consider. 150 Second, we identify the micro-level factors that underlie that spatial distribution of net benefits 151 and that result in some farmers having significant gains compared to others. By modeling a 152 basic component of hydrology, the lateral movement of water, we add spatial detail to our model 153 that captures an important element of realism that farmers encounter and which will help 154 determine more realistically the height of water that farmers face and the particular benefit that 155 they will experience from a groundwater management policy. The distribution of net benefits 156 can be important when considering how politically feasible a policy is; if the median user does 157 not benefit from a given policy we can expect that the policy may be difficult to implement in a 158 popular vote. The distribution of net benefits may also be important to policy design because 159 some farmers may have large gains from a policy even though the average gains are 160 insignificant.

Our results for the Ogallala aquifer in the northwest section of Kansas suggest that simple 162 pricing policies and quantity restrictions may not be very effective and achieve small net benefits 
163 because of their spatially uniform properties. These results are subject to a number of 164 assumptions to be generalizable to other groundwater management situations; parts of the aquifer 165 are depletable in the near future without chance of recovery, there is heterogeneity across the 166 aquifer in physical or demand characteristics, sources of stochasticity are not important to net 167 benefits over the long term, the ability to substitute to surface water supplies are limited, and 168 there are no additional restrictions or rules effecting groundwater management. A sobering 169 finding is that simple water markets that do not account for the possibility of local aquifer 170 depletion can actually perform worse over the life of the aquifer compared to simple pricing 171 policies because they allocate water to places with high marginal returns in a given period, but 172 those same places run out of water earlier which becomes detrimental to the benefits of the 173 policy over time suggesting to us that more spatially or temporally complex markets could be a 174 productive institution for which to search. There is a wide variation in returns from each policy 175 and we do not find overall popular support, by majority rule, for the simple aquifer wide policies. 176 But we find significant gains in certain areas of the aquifer that we study, and significant 177 improvements in water markets when locally restricted. This suggests the possibility of finding 178 popular support for restrictive policies by targeting areas with large potential gains and 179 announcing a need for localized management policies in those areas. Through uncovering the 180 distribution of net benefits from each policy we can identify the factors determining those net 181 benefits. For all policies evaluated in this article, the areas that gain the most are the areas in the 182 aquifer that run dry in the absence of a policy for which farmers can no longer irrigate the land. 183 Other areas with high net benefits are those with higher per acre return from irrigation and lower 184 extraction costs, ceteris paribus. 


\section{Governance}

187 We apply our economic/hydrologic model to the northwest section of Kansas where policy 188 makers are considering conservation measures in an attempt to better manage the Ogallala 189 aquifer. The Governor of Kansas has proposed a form of water markets referred to as water 190 banking. Water banking was set up in 2005 with the goal of restoring flows to water scarce areas 191 and to support water trading in central Kansas (Central Kansas Water Bank Association Five 192 Year Review and Recommendations 2011). The water bank oversees the deposit, sale or lease of 193 water rights and receives a small fee for each transaction it facilitates but has been utilized by 194 few farmers so far. Water rights deposited in the bank are limited to the quantity historically 195 used by the farmer, which may be less than the authorized water right so that unused water rights 196 are restricted from transfer. Under water banking, water available for use must be reduced by a 197 minimum of $10 \%$. There are two forms of reductions possible: a $15 \%$ consumptive use reduction 198 that is applied when a water right is deposited in the bank and another 5-12\% conservation 199 reduction when leasing a water right. These reductions are required under current policy to be 200 taken together, so that first a 15\% reduction is applied when the water is banked then a minimum 201 of an additional $5 \%$ is reduced from the balance. ${ }^{3}$ These reductions are meant to encourage less

202 water use but may be a deterrent to participation in the water market because they act as a 203 penalty to participation. There is an important distinction between being voluntarily subject to a 204 reduction in water use ex post in order to take part in a trading program versus everyone being 205 subject to a reduction ex ante and then taking part in a voluntary trading program. Also if the 206 authorized water extraction is not binding before using the water bank then there is not much 207 benefit in participating in the water market for an individual farmer. These reasons may explain 
why the bank has been used infrequently so far. This observation motivates our model of a water market where restrictions are made up front and then trading for water rights may occur.

Current legal structures in Kansas make aquifer-wide trading difficult. For example, each trade involves a revision to the water right of the buyer and seller, which must be approved by the Division of Water Resources. Among the requirements the trade must meet is that both parties are extracting water from the same "local source of supply." Further, the increased pumping by the buyer must not impair the water rights of her neighbors by reducing their water availability. In Kansas, these requirements are difficult to meet. For the purpose of our analysis, we consider a well-functioning market where water can be traded freely and costlessly among farmers at any given point in time, although we recognize that this would require major changes and redefinitions of water rights as they are currently defined in northwest Kansas.

An alternative to markets are spatially non-uniform policies such as quantity restrictions tied to local hydrologic conditions. Kansas has legislated the opportunity for localized areas within the Ogallala to form and create their own management plans, the LEMAs. There are six LEMAs within our area of study in northwest Kansas, but only one of these LEMAs has actively moved to reduce water extraction. The idea behind these smaller sub units within the aquifer is that by allowing more homogeneous communities to form institutions and rules there may be more incentives for them to voluntarily reduce collective water usage. The one active LEMA, Sheridan County 6 High Priority Area (SD-6 HPA), is the first LEMA to be created in Kansas, in 2012, and has initiated management plans that involve a 20\% reduction of their 2010 authorized limits to groundwater extraction by well. (See http://gmd4.org/ (SD-6 HPA enhanced management proposal) for more detail.) Unrestricted trading between water right holders is 
230 allowed within the LEMA. However, to date there have been no trades between water right 231 holders within SD-6 HPA.

\section{Model}

We construct a multi-cell model of an aquifer in which groundwater flow is governed by 235 Darcy's Law. Darcy's Law is an equation used in hydrology that relates the characteristics of the 236 aquifer (eg. soil type, hydraulic gradient) to the volume of water that flows from one area in the 237 aquifer to another adjacent area in the aquifer in a given period of time. The model is 238 constructed with $N$ cells $(n=1,2, \ldots, N)$ and $I$ farmers $(i=1,2, \ldots, I<N)$ that exist on a subset 239 of the cells that overlies the aquifer, meaning that there are areas of land above the aquifer that 240 are not irrigated. Farmers are stationary and choose the amount of water to extract from their 241 well to irrigate crops. Each farmer occupies no more than a single cell and there is only one

242 farmer on each cell. Furthermore, each farmer owns only a single well so that there are $(I<N)$ 243 wells in our model. Because a farmer cannot occupy more than one cell and nor can there be 244 multiple farmers on any given cell we ensure a unique mapping between cells, wells and farmers 245 and these terms can be used interchangeably in the text that follows. To simplify notation, we 246 refer to the cell occupied by farmer $i$ as cell $i$ and the well owned by farmer $i$ as well $i$.

247 Many studies assume a bottomless aquifer in order to evaluate the extraction path of 248 water as it goes to the steady state. We institute an uneven bottom to the aquifer that is location 249 specific, an accurate representation of the Kansas aquifer modeled in this article. The 250 significance of instituting a bottom that varies throughout the aquifer is that some cells of the 251 aquifer that save water increase flows to adjacent areas with lower levels of water, thus 252 extending the life of those cells of the aquifer and delaying or avoiding potentially large losses. 


$$
W_{i t}=g_{i}+k_{i} P_{i t}
$$

256

257 where $W_{i t}$ is the volume of water demanded (acre feet), $g_{i}>0$ and $k_{i}<0$ are demand parameters 258 and $P_{i t}$ is the price of water (\$/acre feet) for farmer $i$ at time $t$ (years). We assume that wells are 259 dug deep enough to extract up to the maximum depth possible so the only cost to the farmer is 260 the marginal pumping cost which is determined by the lift water needs to pumped. The marginal 261 pumping cost for farmer $i, \bar{P}_{i t}$, is thus given by:

262

$$
\bar{P}_{i t}=C_{1}\left(L S_{i}-H_{i t}\right)
$$
lift, $L S_{i}$ is the land surface elevation faced by farmer $i$ (feet) and $H_{i t}$ is the water level (feet) in the single well owned by farmer $i$ at time $t$, and the differential between them is the lift (feet) that farmers must pump water to irrigate their crops. The equation of motion for the height of water 269 in farmer $i$ 's well is defined as

$$
H_{i, t+1}-H_{i t}=\frac{R_{i}}{A_{i} S}-\sum_{j \neq i}^{J}\left(\frac{K_{i} C A_{i j t}\left(H_{i t}-H_{j t}\right)}{d_{i j} A_{i} S}\right)-\frac{(1-\alpha) W_{i t}}{A_{i} S}
$$

272 where $R_{i}$ is volumetric natural recharge (acre feet), and, $K_{i}$, hydraulic conductivity (feet/year) 273 describes the nature of the soil that water flows through is location specific but time invariant. 274 Specific yield ${ }^{4}, S$ (unitless), is the volume of water a unit of soil can hold and $\alpha$, the return 
275 coefficient, is the fraction of water extracted that percolates back into the aquifer. $A_{i}$ is the

276 surface area of the land that a farmer inhabits (acres) and $C A_{i j t}$ is the cross-sectional area through

277 which water flows between the cells adjacent to farmer $i$ 's cell (acres). The cross-sectional area,

278 the area that water flows through, changes over time by the average of the saturated thickness

279 between two adjoining cells: if water is extracted faster than the natural recharge and lateral

280 flows can replenish the cell, the saturated thickness for that cell will decrease as will the cross-

281 sectional area. $J$ is the number of adjacent cells that share a side with cell $i$. The distance

282 between adjacent cells $i$ and $j, d_{i j}$ (feet), is equal to the distance between the centroid of each cell.

283 Including the interaction term between cells creates the difference between a model with finite

284 hydraulic conductivity such as this model and the bathtub model that implicitly has instantaneous

285 lateral groundwater flows.

286

The aquifer is restricted to have a cell specific bottom with elevation $B_{i}$ (feet), which

287 dictates the minimum height of water in a cell. Water can still flow through cells until there is no 288 water left; when saturated thickness is equal to zero water can only flow into the cell. Farmers 289 on the other hand can only pump water until saturated thickness is equal to $\delta$ as stated in 290 Equation (4)

$$
W_{i t}=\left\{\begin{array}{l}
=0 \text { if } H_{i t}<B_{i}+\delta \\
>0 \text { if } H_{i t} \geq B_{i}+\delta
\end{array}\right.
$$

293 Farmers face this constraint because pumping becomes infeasible before saturated thickness reaches zero: as saturated thickness is reduced a greater amount of soil and rock gets pumped up 295 with the groundwater eventually making it impossible to pump water. Once the water level in 296 farmer $i$ 's well reaches this level of saturated thickness it can no longer be pumped for the rest of 297 the simulation, that is, we assume that the natural recharge is small enough that once wells go 
298 dry they are typically not usable for irrigation any longer and the cessation of irrigation is

299 irreversible. While this is not always the case in practice, it is true that once wells go dry they

300 are typically not used for irrigation again; for institutional reasons farmers lose legal access to

301 the water rights when they go unused in Kansas.

303 Farmer Behavior

304 To evaluate alternative water management policies in our model we assume a baseline farmer 305 behavior, apply policy scenarios, and evaluate the private net benefit resulting from a given 306 policy. Our baseline assumption is that farmers are myopic and each farmer $i$ maximizes her 307 private net benefit from agriculture in each period sequentially, with no multi-period decision308 making considered and without regard to other use or non-use values associated with water use. 309 This myopic behavior is referred to as competitive pumping in much of the groundwater 310 literature. The reasons for assuming this behavior are as follows: 1) it has been empirically 311 difficult to reject myopic farmer behavior (Savage and Brozovic 2011; Suter et al. 2012), 2) Karp 312 (2012) shows that when there are more than a few agents extracting a common pool resource that 313 open-access behavior is a good approximation under many conditions, and 3) in a complex 314 spatial groundwater model the informational assumptions needed to assume individual strategic 315 behavior across the aquifer are high. For example, it seems unrealistic to assume that a farmer 316 knows all current and future lateral flows through the aquifer and will engage in the iterative 317 process needed to calculate a best response extraction path in a detailed model of an aquifer. 


$$
\text { Net Benefit }{ }_{i t}=\frac{W_{i t}^{2}}{2 k_{i}}-\frac{g_{i} W_{i t}}{k_{i}}-C_{1}\left(L S_{i}-H_{i t}\right) W_{i t} \text {. }
$$
pumping cost:

$$
\frac{W_{i t}}{k_{i}}-\frac{g_{i}}{k_{i}}=C_{1}\left(L S_{i}-H_{i t}\right)=\bar{P}_{i t}
$$

$$
\text { DiscountedNB } B_{i t}=\sum_{i}^{I} \sum_{t}^{T} \frac{1}{(1+r)^{t}}\left(\frac{W_{i t}^{2}}{2 k_{i}}-\frac{g_{i} W_{i t}}{k_{i}}-C_{1}\left(L S_{i}-H_{i t}\right) W_{i t}\right) \text {. }
$$
maximizing Equation (7) subject to the constraints of each policy (in addition to the other model constraints) and comparing the net benefit to that obtained under the baseline scenario of myopic competitive pumping in the absence of any policy restrictions. In effect, this amounts to defining the policy instrument as the control variable to find the optimal constrained policy. In the base 
342 case scenario farmers are restricted to pumping up to their 2010 authorized limit. ${ }^{5}$ The

343 authorized limit is assigned by the Kansas Water Authority and puts a cap on the acre feet of

344 water allowed to be pumped by a well.

Flat Tax

347 The flat tax is defined in this paper as a tax that is uniform across all the farmers in the aquifer as 348 well as constant over time. That is, the tax raises the per unit price of water for all farmers by the 349 same percentage. In the base case farmers choose $W_{i t}$ defined by the price of water in Equation 350 (2). With a flat tax farmers choose $W_{i t}$ defined by the price of water in Equation (8). Note that 351 because of differences in location relative to other farmers, height of water in the well, and 352 spatial variation in the physical properties of the aquifer each farmer is affected differently by the 353 flat tax even though all farmers face an identical tax rate. In particular, farmers with a greater lift 354 face a higher tax in dollar terms compared to farmers with lower lift. 356 marginal cost of extraction in the face of the optimal flat tax as described in Equation (9). 357 Discounted net benefit is measured by Equation (7) and the flat tax rate chosen is the one that maximizes the value of this equation which is the net benefit, a tax refunded net benefit. This

359 captures the benefit of reduced groundwater pumping while making the results comparable to 360 other non-tax based policies.

$$
\bar{P}_{i t}=C_{1}\left(L S_{i}-H_{i t}\right) *(1+\text { Taxrate })
$$

$$
\frac{W_{i t}}{k_{i}}-\frac{g_{i}}{k_{i}}=C_{1}\left(L S_{i}-H_{i t}\right) *(1+\text { Taxrate })
$$


366 The variable tax is a tax that is uniform across all the farmers in the aquifer but is allowed to vary 367 over time. We find the optimal variable tax that maximizes the discounted net benefit over the 368 entire aquifer. With a variable tax farmers choose $W_{i t}$ defined by the price of water in Equation 369 (10). Farmers set the marginal benefit of extraction equal to the marginal cost of extraction in 370 the face of the variable tax as shown in Equation (11). For the sake of computational ease, we 371 restrict taxes to change six times over the course of the simulation: as the number of parameters 372 to be estimated increase the parameter space increases exponentially making it numerically very 373 burdensome in a detailed model like ours. ${ }^{6}$ Discounted net benefit over the entire aquifer is 374 again measured by Equation (7) which is the tax refunded net benefit.

375

376

$$
\bar{P}_{i t}=C_{1}\left(L S_{i}-H_{i t}\right) *\left(1+\text { Taxrate }_{t}\right)
$$

$$
\frac{W_{i t}}{k_{i}}-\frac{g_{i}}{k_{i}}=C_{1}\left(L S_{i}-H_{i t}\right) *\left(1+\text { Taxrate }_{t}\right)
$$

It is important to note that in both the flat and variable tax scenarios, we assume that the tax revenue raised is returned to the farmers through a non-distortionary lump sum transfer so 382 that the net benefits may be calculated without the tax and given by equation (7). This simplifies 383 the comparison between tax policies, quantity restrictions, and water markets.

\section{Quantity Restrictions}

386 In Kansas, each well is restricted to a maximum quantity of water extracted per year. In this 387 scenario we use the acre feet per well allocated in 2010 to set this limit and explore cases where 
388 this limit is reduced by the same percentage for all farmers, like a uniform rollback of the 389 authorized water rights. Farmers will behave just as they have in the base case scenario but will 390 only be allowed to extract up to the volume of water defined by the limit in Equation (12)

391

392

393

394 395 396 397 398 399 400 401 402 403 404 405 406 given by Equation (13)

407

408

$$
\mathcal{L}=\sum_{i}^{I}\left(\frac{W_{i t}^{2}}{2 k_{i}}-\frac{g_{i}}{k_{i}} W_{i t}-C_{1}\left(L S_{i}-H_{i t}\right) W_{i t}\right)-\lambda_{t}\left(\sum_{i}^{I} W_{i t}-\bar{W}\right)
$$

$$
W_{i t} \leq(1-x) * \text { Limit }_{i, 2010}
$$

where $x$ refers to the percentage reduction below the 2010 allocated limit for farmer $i$. Equation (6) still describes the behavior of the farmer in a given period but now farmers are restricted by Equation (12). As before, discounted net benefit is measured by Equation (7).

\section{Water Market}

In this section we describe the properties of the water market and formalize the equilibrium state that exists when a market is established. We describe the water market as a static problem with a constraint on the total water extracted in any period, $\overline{W_{t}}$ (total number of permits issued) but with no other constraints such as those due to local depletion arising from the market itself. In this water market, farmers are not constrained by individual limits but by the final number of permits they hold. The aggregate net benefit in any period is given by the expression in parentheses in equation (7) and is subject to the constraint that $\sum_{i}^{I} W_{i t} \leq \overline{W_{t}}$. The Lagrangian for the problem is 
410 where the height of water, $H_{i t}$, in any period is determined by the actions of the farmers in the

411 previous periods, but is considered exogenous in this problem. The solution to (13) gives the

412 optimal allocation of water across farmers at a point in time, but does not insure an optimal

413 allocation of water to farmers over time. At the optimum, the marginal net benefit is equalized

414 across all farmers, and is equal to the permit price, $\lambda_{t}$, so that

415

416

$$
\frac{W_{i t}}{k_{i}}-\frac{g_{i}}{k_{i}}-C_{1}\left(L S_{i}-H_{i t}\right)=\frac{W_{j t}}{k_{j}}-\frac{g_{j}}{k_{j}}-C_{1}\left(L S_{j}-H_{j t}\right)=\lambda_{t} \quad \forall i \neq j .
$$

By substituting Equation (14) into the constraint that total water extracted cannot exceed $\overline{W_{t}}$, we retrieve the optimal allocation of water as

$$
W^{*}{ }_{i t}=\frac{\overline{W_{t}}+C_{1} \sum_{j \neq i}^{J}\left[\left(\left(L S_{i}-H_{i t}\right)-\left(L S_{j}-H_{j t}\right)\right) k_{j}\right]+\sum_{j \neq i}^{J}\left(\frac{g_{i}}{k_{i}}-\frac{g_{j}}{k_{j}}\right) k_{j}}{\sum_{j \neq i}^{J}\left(\frac{k_{j}}{k_{i}}\right)+1} .
$$

424 there are no further benefits from trade. Intuitively we can think of three main components 425 deciding the allocation--acres irrigated, cost of extraction, and marginal productivity of the land. 426 More acreage, less cost, and highly productive land gets larger allocations of water. The 427 denominator of equation (15) accounts for relative number of acres irrigated compared to the 428 other farmers: holding lift and other factors determining the productivity of irrigation constant, 429 the only difference between the water demand across farmers, and therefore between $k_{i}$ and $k_{j}$, is 430 due to a difference in the number of acres irrigated in cells $i$ and $j$. A farmer with more acres 
431 irrigated gets a higher allocation from the water market, ceteris paribus. In addition, since the

432 marginal extraction cost per additional foot of lift is the same across all farmers, extraction cost

433 differences are determined by the current period lift, $L S_{i}-H_{i t}$, with farmers receiving larger

434 allocations when they have smaller current period lift and therefore extraction costs. The ratio

$435 g_{i} / k_{i}$ is the intercept in the inverse demand function for water and reflects the marginal

436 productivity of irrigation: it captures the effects of unobservables such as soil quality and micro

437 climate which lead to different yields per acre. The more productive farmers receive larger

438 allocations of water. ${ }^{7}$

439 We assume there is an interior solution and that the total water constraint is binding at 440 each time period. Farmers who run out of water at their location are forced to shut down and 441 cannot participate in the market. The farmer specific net benefit from trading permits depend on 442 the initial allocation of permits which can be manipulated to make all farmers better off, or any 443 other distribution of gains that are desired. We focus on the final distribution of water allocated 444 by the water market to farmers and compare it directly to the welfare of farmers under perfect 445 competition to simplify the analysis. As before, aggregate discounted net benefit is measured by 446 Equation (7). $\overline{W_{t}}$ comes from the given constraint, since we layer the water market on top of 447 other policies $\overline{W_{t}}$ will be the total water quantities retrieved by a simple pricing or quantity 448 policy in each period.

Local Management Policies

451 The local management policies mimic the policies over the whole aquifer, as given in the 452 sections above except each policy is applied to one local management area. Farmers in that area 453 are subject to the simple policy while farmers outside of the local management area are left to the 
454 baseline behavior of myopic pumping. For the pricing policies and quantity restrictions only the

455 local management area is subject to the tax or quantity restriction as given by Equations (8) and

456 (10), respectively. For the water market trading is restricted to the local management area, and

457 the local area restriction, $\overline{W_{t}}$, is the total water quantities retrieved by a simple pricing or quantity

458 policy in each period from the local management area. Each farmer in the market over the local

459 management area is allocated water as defined by Equation (15). The discounted net benefits are

460 calculated as before with Equation (7) for all policies.

461

462 Data

463 We calibrate our model to the northwest Kansas section of the Ogallala aquifer using detailed 464 data sources of water demand and of location specific physical properties of the aquifer. We 465 obtain spatially detailed parameters of hydraulic conductivity, saturated thickness, and natural 466 recharge through the Kansas Water Office (KWO). Summary descriptive statistics of the 467 physical properties of the aquifer are given in table 1 . We should note that when calibrating our 468 model to the Kansas data where there are multiple farmers occupying the geographical area 469 delineated by a single cell in our model, we aggregate those farmers into a single representative 470 farmer for that cell. We run each model simulation for ninety periods as the discounted net 471 benefit becomes insignificant beyond this point, with each period representing one year. ${ }^{8}$

473 Water Demand Estimates

474 We estimate water demand from a field level panel of observations utilized by Hendricks and 475 Peterson (2012) for the Groundwater District 4 section of Kansas that we study. Following 476 Hendricks and Peterson (2012), we construct a linear per acre demand curve for water and apply 
477 our estimates to farmers in the model via GIS maps of field location and documented irrigated 478 acreage of the fields. We incorporate spatial fixed effects to control for unobservable spatial 479 characteristics, such as soil productivity. The unit of observation for this dataset is the individual 480 well; water use and well depth are self-reported by farmers from 1992 to 2007, in an unbalanced 481 panel. Equation (16) describes the equation estimated,

482

483

484

485

486

487

488

489

490

491

492

493

494

495

496

497

498

499

$$
\begin{gathered}
A W_{i t}=\beta^{0}+\beta^{1}\left(C P_{i t}\right)+\beta^{2}\left(P 1_{i t}\right)+\beta^{3}\left(P 2_{i t}\right)+\beta^{4}\left(E V_{i t}\right)+\text { Spatial fixed effects } \\
+ \text { TimeDummies }+\varepsilon_{i t}(16)
\end{gathered}
$$

where $A W_{i t}$ is the applied acre feet of water per acre, $C P_{i t}$ is the cost of pumping an acre foot of water one foot in lift, $P 1_{i t}$ is the precipitation from January to April in inches, $P 2_{i t}$ is the precipitation from May to August in inches, $E V_{i t}$ is evapotranspiration from May to August in inches, TimeDummies are individual dummy effects for each year that track aggregate changes over time, whereas spatial fixed effects account for time invariant differences across space such as soil quality and are consistent in size and space with the cells of the groundwater model as defined in the simulations. $\varepsilon_{i t}$ is the error term. The summary statistics for these variables are shown in table 2 . The price (pumping cost) of water to a farmer is determined by energy prices and the vertical distance that water is pumped.

We estimate Equation (16) using ordinary least squares. We do not specify crop choice or technology so that these variables vary along the demand curve. In effect this provides an estimate of an average long run demand curve implicitly changing crop and technology over time based on the farmer's location on the demand curve. For simplicity we do not investigate the change in acreage associated with a change in the price of water but focus solely on the reduction 
500 of water used due to an increase in the price of water and hold acres irrigated constant for a cell 501 throughout the simulations. The results for the water demand estimates are given in table 3.

502 The slope of demand curve for groundwater is given by the estimated coefficient on the 503 pumping cost, $\beta^{1}=-0.00395$. We use the spatial fixed effects $\left(S F E_{i}\right)$ estimated from equation (16) 504 as parameters in the simulation model, specifically as the per acre intercept for each cell in the 505 model. To specify our model consistently with the data we estimate the average slope of the 506 water demand per acre curve across the region of study, but allow for intercepts to shift by cells 507 for differences in micro-climates or productivity of the land. This means that while each 508 representative farmer in the simulation model has a common per acre slope of the demand curve 509 they have different per acre intercepts. Furthermore, even when the per acre slope and intercept 510 are the same for two farmers in the simulation model, total water demanded may still be different 511 because of differences in the number of irrigated acres (determined by the water use data from 512 KWO). Thus, the demand curve for water per irrigated acre is parameterized as

$$
A W_{i t}=S F E_{i}-0.00395 * P_{i t} .
$$

\section{Ogallala Aquifer Properties}

517 The KWO provided detailed estimates of hydraulic conductivity, saturated thickness, and natural 518 recharge in GIS maps that are equivalent to cells in our model. For the land surface parameter 519 we use the 2013 National Elevation Dataset (NED) in the form of 1 arc seconds, sourced from 520 the United States Geological Survey. We inform our model with these detailed spatial 521 descriptions of the physical properties of the aquifer. 
We collect the water demand estimates and physical parameters of the aquifer and import

523 them into the model using NetLogo, software employed in agent-based models. ${ }^{9}$ Figure 2 depicts

524 the northwestern Kansas section of the Ogallala aquifer that we model, where grey cells with

525 black dots represent areas that farmers irrigate and white cells represent land over the aquifer that

526 is not irrigated. Black cells are areas that are not a part of the aquifer. We take the linear

527 demand per acre given in Equation (17) and multiply that by the acreage irrigated in a cell to

528 determine the demand for water in a given cell, and for a given representative farmer in that cell.

529 This provides a heterogeneous spatial estimate of water demand across the aquifer. The areas

530 that border the north and west sides of the aquifer are assumed to have no lateral flows with the

531 aquifer, this may over or under estimate the lateral flows depending on actual height of water in

532 those locations.

533 Model Validation

534 To validate the model we use 2001 estimates of saturated thickness and height of water in cells, 535 the long run averages of the hydraulic conductivity and recharge provided by the KWO, the 536 elevation data from the NED and the per acre demand for water from equation (17) and predict 537 the height of water in each cell in the aquifer in 2010. We interpolate the height of water in the 538 aquifer at both 2001 and 2010 using the well data from these years and smoothing these heights 539 over the rest of the aquifer using the interpolation function and Inverse Distance Weighted 540 method available in ArcGIS using the nearest 15 wells and a power of 2. This experiment 541 verifies our ability to predict the dynamics of the aquifer being modeled. We retrieve a high 542 correlation coefficient of 0.99 where the predicted height of water in the cells explains the actual 543 height of water in $2010 . .^{10}$ 
546 The five policy scenarios we investigate are: 1) a flat tax over time and space (FT), 2) a variable

547 tax that changes over time but is the same for all farmers (VT), 3) quantity restrictions on the

548 authorized amount of pumped water, 4) a water market with total water pumped equal to the

549 amount pumped under the other three policies, in essence the water market is layered on top of

550 the other policies investigated, and 5) Local Area Management scenarios. Table 4 contains the

551 results for the two pricing scenarios, the quantity restrictions, and relevant water market

552 counterparts. Since our choice of the discount rate $(3 \%)$ is somewhat arbitrary, we test our

553 results under a $1 \%$ and $5 \%$ discount rate as well. We find that when discount rates are lower

554 (higher) the overall gains in all policies increase (decrease) but the relative differences in those

555 policies are similar to main results in reported in Table 4 and we do not report the results under

556 the alternative discount rates.

557 The extraction path of groundwater for the entire aquifer under these scenarios is given in

558 figure 3. It is important to note that we restrict the amount of water pumped by farmers to their 5592010 authorized water limit in the base case (no policy) scenario -- 476 acre feet of water in the

560 initial period and limited to a few farmers only -- although this restriction affects the solution

561 minimally because it is a small amount of water, $0.13 \%$ of the total. The extraction paths for the

562 flat tax and variable tax are quite similar (but not identical), and because of this the overall

563 implications of the policies are similar as well. This suggests that varying the tax over time does

564 not substantially change the aggregate net benefit compared to a policy that is both spatially and

565 temporally uniform. The base case and quantity restricted scenario extraction paths are on top of

566 each other in figure 3. The scenario with the optimal quantity restricted, $98 \%$ of the 2010

567 authorized limit, in fact uses roughly $0.1 \%$ less water than the base case.

568 Flat Tax 
569 As reported in table 2, a $1.02 \%$ gain in aquifer-wide net benefits is obtained under a flat tax of $570547 \%$ relative to the base case scenario with no policy and myopic farmer behavior. The high

571 level of tax is a function of the low price elasticity of demand for water. As shown in figure 4, 572 overall gains in net benefit are not very sensitive to small changes in tax rates, with average gains 573 of around $1 \%$ and a wide range of tax rates providing roughly the same amount of overall gains.

574 The optimal flat tax appears to be very high, which may cause shutdown when not returned as a 575 lump sum transfer or be politically unpopular. This makes the flat tax pricing policy relatively 576 unattractive.

While the simple tax policy does not retrieve much net benefit for farmers in total, there 578 is substantial heterogeneity in the distribution of gains across farmers with some farmers 579 experiencing a net benefit well above 50\%. The median farmer under this scenario is worse off 580 with a negative return from this policy, which suggests that this policy will likely be unattractive 581 to a majority of farmers. Figure 5 shows a scatterplot of individual farmer's gains under the 582 optimal flat tax policy with the dollar gains on the x-axis and the percent gains on the y-axis. 583 This scatterplot shows a high density of farmers around the origin $(0,0)$, showing that most 584 farmers gain little to no advantage from the policy. The farmers that benefit the most from this 585 policy are generally ones that are located in cells that run out of water under the status quo and 586 this policy allows them to irrigate the land further into the future and increase their welfare.

587 We examine the two farmers with the highest net benefits in dollars under the optimal flat 588 tax scenario indicated in figure 5 by the diamonds that are circled. These two farmers have 589 relatively large amount of irrigated acreage and a small saturated thickness that lead them to 590 exhaust the groundwater resources in their area of the aquifer under the base case, whereas the 591 flat tax extends the life of the aquifer at their wells. But a uniform policy that greatly benefits 
592 these two farmers does not benefit the majority of farmers because it causes the majority of 593 farmers to save either too much or too little water. The farmers with the largest percentage 594 losses are ones that under the optimal flat tax cannot consume any water because the price is 595 above their choke price. There are only three farmers this applies to and the size of their 596 negative net benefits is relatively small and not material to the total gains for the aquifer.

597 Variable Tax Results

598 The variable tax does not improve much on efficiency when compared to the flat tax, capturing 599 approximately the same amount of the potential gains on average. We find the optimal variable 600 tax is decreasing over time starting from $547 \%$ and declining to $379 \%$ by the end of the 90 year 601 horizon.

602 The distribution of gains from the variable tax is essentially identical to the flat tax 603 distribution which suggests that the time component by itself does not substantially improve or 604 change gains when the tax policy is uniform over space and time. The general characteristics of 605 the farmers with positive and negative net benefits under this policy are also the same as the flat 606 tax scenario.

607

608 Quantity Restriction Results

609 Using 2010 authorized acre feet of water limits by well, we simulate a policy that explores 610 uniform reductions to those limits and measure the effects on discounted net benefits. The 611 spatial component to this policy differs from the uniform tax policies in two important ways. 612 First, the uniform tax based pricing policies will be more burdensome for farmers that have a 613 larger lift, whereas the quantity restrictions are not necessarily correlated with amount of lift a 614 farmer faces. Second, the potential burden that a farmer faces from a quantity restriction 
615 depends on the gap between the authorized limit of acre feet of water and the profit maximizing

616 amount of water. This gap is not uniform over the aquifer and can be large for some farmers

617 which means that a reduction in the limit is not binding for some farmers. Figure 6 shows the

618 gains to discounted net benefit for the aquifer from the corresponding quantity restriction. The

619 quantity restrictions do not yield much net benefit and perform increasingly worse as they

620 become more severe.

621

The optimal quantity restriction is $98 \%$ of the 2010 authorized limit, or a reduction of $2 \%$

622 below the baseline. This yields a much smaller savings in water extracted because it is a small

623 reduction in limits and the non-binding effect it has on some farmers. And this policy yields a

624 much smaller increase in overall net benefit compared to the simple tax policy because of the

625 spatial distribution of the quantity restriction.

626 Water Markets Results

627 We investigate a simple, static water market that functions like a cap and trade policy. The 628 overall quantity of water extracted in each period is set exogenously and trading for water 629 permits occurs in each period separately. The initial distribution of water rights has no effect on 630 the total gains but only the distribution of gains to individual farmers. We evaluate the 631 distribution of gains in total where permits are handed out to the final users efficiently, as if no 632 trades were needed for ease of comparison. To reveal the overall benefit of adding a market for 633 water permits we choose the total water extraction profiles produced in subsections Flat Tax 634 Results, Variable Tax Results, and Quantity Restriction Results with the water market 635 determining the allocation of water within a period to the individual farmers rather than a 636 spatially uniform policy. It is also important to realize that only the total aquifer quantity 637 restrictions are binding and individual quantity restrictions are removed in these scenarios. 
638 Individual quantity restrictions that are binding would complicate the analysis and do not fit the 639 goal to meet that overall water restriction and provide the optimal individual allocation in one 640 time period.

641 There are small increases and in some cases decreases in overall net benefits from 642 instituting markets compared to pricing and quantity policies. The main reason for the relatively 643 poor performance of the water market is that it puts no explicit value on a well drying up and 644 allocates water to the highest marginal users each time period. This creates a potential tradeoff 645 between current period allocative efficiency benefits and future benefits from avoided 646 exhaustion. Farmers can choose to participate in the water market, and always benefit when they 647 choose to do so. But farmers can do worse in the water market when compared to other policy 648 scenarios. We compare the water markets, which includes a restriction on the total quantity of 649 water extracted, to the baseline scenario of no restrictions. A negative return from the water 650 market means that even with the ability of buying or selling water permits, given their allocation 651 of permits the farmer is worse off than if there were no restrictions and no water market over the 652 time of the simulation. This fact causes an inefficiency that is greater than the single period 653 allocative benefits that are provided in the market mainly because the correlation between thin 654 saturated thickness and high immediate marginal returns from groundwater. Nonetheless, it is 655 worth noting the considerable heterogeneity in the distribution of net benefits under the water 656 markets. In the water markets with flat tax quantities (WMFT) scenario the farmers that 657 experience the largest absolute increase in private net benefit are generally those that have small 658 saturated thickness, and the life of their section of the aquifer is extended by a small decrease in 659 pumping. Interestingly, the farmers that see the highest percentage gains compared to the 660 baseline scenario are allocated less water by the market than under the flat tax scenario and have 
661 thin saturated thickness. These farmers inadvertently benefit from the market because their life

662 of their well is extended and therefore experience the largest gains from a market, or stated

663 differently, the flat tax for these farmers was 'too small.' The heterogeneity that drives the water

664 market in our model is obtained from the physical properties of the aquifer (depth to water,

665 saturated thickness, hydraulic conductivity, etc.) and from the variation in water demand (spatial

666 fixed effects, irrigated acreage).

667 The water market with the aggregate quantity of water restricted to be the same as the 668 optimal variable tax (WMVT) quantities is similar to the water market with the aggregate 669 extraction restricted to the optimal flat tax quantities except that it exacerbates the extinction of 670 wells because of higher total withdrawals in the aquifer. The distribution of gains is different 671 compared to the flat tax quantities because some farmers are allocated more water earlier in 672 model horizon in the variable tax scenario than the flat tax scenario. These farmers run out of 673 water earlier under the WMVT scenario and this skews the distribution of gains down even 674 though the overall gains are very similar. This is apparent from the smaller value of the 675 maximum in column (5) of table 4 when compared to column (4) of table 4.

676 The water markets with the quantity restricted to $98 \%$ below the 2010 allocated use or $6772 \%$ below the baseline yields a small improvement in net benefits from slightly over $0 \%$ to $6780.11 \%$, primarily through the improved spatial distribution of water. Here the water market 679 improves upon the allocative efficiency without materially damaging the life of the wells, 680 leading to gains above the straight quantity restrictions.

681 Local Management Results

682 In this section we institute a LEMA in our model of the aquifer and investigate the simple 683 policies when applied to the LEMA only, leaving the rest of the aquifer unrestrained. We 
investigate LEMA SD-6 HPA which resides mostly in Sheridan County in Kansas and is shown in figure 7 by the dark shaded area. In 2012, this LEMA voluntarily instituted a $20 \%$ quantity restriction and we find that this restriction is not binding so that there is no benefit or loss from the policy under our model. So, instead, we apply three policies, a flat tax, a quantity restriction, and a water market, that are optimal for the sum of farmers within SD-6 HPA.

Table 5 shows the results for the farmers in SD-6 HPA when the aquifer wide optimal flat tax is applied to the entire aquifer and when an optimal flat tax for SD-6 HPA is applied just to that LEMA, leaving other areas unregulated. These results show that optimizing the simple pricing policy improves the outcome for the LEMA somewhat--the total net benefit for the LEMA is $5.63 \%$ when the entire aquifer is under the flat tax and $7.25 \%$ when the tax optimized for the LEMA only. The distributions of net benefits in the LEMA are similar between the two results and but the localized policy yields larger gains in overall net benefit for the farmers in the LEMA and widens the distribution by decreasing the minimum gains. The optimal quantity restricted is much higher in the SD-6 HPA than the optimal aquifer wide policy. Instead of a $2 \%$ reduction in authorized pumping, which is nonbinding for farmers in this LEMA, the optimal quantity restricted is $68 \%$. These optimal reductions are much greater than current suggestions in Kansas and they appear to be beneficial to most farmers in the HPA when undertaken jointly.

Furthermore, when the water market is applied to just this LEMA there are substantial benefits, compared to the aquifer wide water market. In particular the water market with quantity restrictions in Table 5, shows that SD-6 could potentially increase discounted net benefits by $11.5 \%$ through large restrictions on pumping and allowing for trading of the water permits. The water market provides a much greater benefit when localized, compared to the 
minimal benefit the simply water market provided over the entire aquifer. This occurs because it water rights are not moved out of the local area where depletion is especially important.

The total net benefit is much higher in this LEMA compared to the total aquifer net benefit from all simple policies, which may be why the LEMA formed in the first place since they have higher than average returns from implementing groundwater management policies.

The farmers have an incentive to form LEMAs and cooperate when the median and total gains are sufficiently high as they may be in SD-6 HPA. This highlights how localized policies may be more beneficial than aquifer-wide policies when there are no other restrictions since the localized policies can substantially improve total benefits and take into consideration local circumstances.

\section{Determinants of Net Benefits}

In this section we analyze how the attributes of the farmers and their location contribute to gains from the simple management policies. We use an ordinary least squares regression to identify the average contribution of natural recharge, $R_{i}$, initial saturated thickness, $S T_{i}$, irrigated acreage, $I A_{i}$, initial lift, $L_{i}$, initial irrigated acreage of neighboring farms ${ }^{11}, N_{i}$, hydraulic conductivity, $K_{i}$, the land elevation at the well $S L_{i}$, the water demand intercept, $W D I_{i}$, and a binary variable to indicate if the farmer's well dries up in the perfect competition scenario, $D R Y_{i}$, to individual present value gain in net benefit, $N B$. We include squared terms of all the variables to capture non-linearities. We split the observations into two groups, farmers that gain from the policy and farmers that do not gain from the policy when compared to the baseline scenario. The farmers that gain a positive amount from the policy are generally the farmers who have the life of their well extended before it dries up, but the categories are not perfectly correlated. A change in net benefit is recorded as a percentage gain (loss) above (below) the perfect competition net benefit 
729 for farmer $i$. Equation (18) describes the equation estimated and the results are reported in table

730

731

732

733

734

735

736

737

738

739

740

741

742

743

744

745

746

747

748

749

750

751

752

6.

$$
\begin{array}{r}
N B_{i}=\beta^{0}+\beta^{1}\left(R_{i}\right)+\beta^{2}\left(S T_{i}\right)+\beta^{3}\left(I A_{i}\right)+\beta^{4}\left(L_{i}\right)+\beta^{5}\left(N_{i}\right)+\beta^{6}\left(K_{i}\right)+\beta^{6}\left(E L_{i}\right)+\beta^{7}\left(W D I_{i}\right)+\beta^{8}\left(D R Y_{i}\right) \\
+\beta^{9}\left(R_{i}^{2}\right)+\beta^{10}\left(S T_{i}^{2}\right)+\beta^{11}\left(I A_{i}^{2}\right)+\beta^{12}\left(L_{i}^{2}\right)+\beta^{13}\left(N_{i}^{2}\right)+\beta^{14}\left(K_{i}^{2}\right)+\beta^{15}\left(E L_{i}^{2}\right)+\varepsilon_{i}
\end{array}
$$

We only report the results from the flat tax scenarios because they are very similar to the variable tax results. It is apparent that the flat tax yielded an increase in net benefit because it extends the life of the aquifer in certain areas, the water market does this to a lesser extent. Farmers with positive net benefit under a flat tax policy, column (2) of table 6, exhibit a negative association between the percentage gain and saturated thickness. A larger saturated thickness leads to smaller gains because the farmers are less likely to run out of water. To a lesser extent more productive areas, as indicated by the larger demand intercept, and areas with smaller lift gain more as well, as shown in column (2) of table 6.

Figure 8 shows the spatial distribution of the farmers with an increase in net benefits under a flat tax policy, represented by the shaded cells. When compared to figure 1 there is an obvious correlation between the areas of the aquifer that have a short life span and the locations with an increase in net benefit.

In column (1) of table 6, we investigate the farmers that experience a negative net benefit under the flat tax policy, that is, the farmers that are worse off than if there was no policy at all. Of the farmers whose net benefits decline under the flat tax, the ones that do worse have less productive land and whose wells don't run dry. This result is driven by the fact that these farmers have lower marginal benefits from irrigation in each time period and with a large saturated thickness the wells do not dry up in the baseline scenario. 
When water is allocated through a water market the distribution of water use changes in 754 each time period, but we see a similar set of correlates driving the results. Column (4) of table 6 755 shows the results for farmers with an increase in net benefits under a water market compared to 756 the baseline scenario. Farmers with smaller saturated thickness and smaller lift see larger 757 increases in net benefits: areas with a smaller lift have smaller extraction costs on average and 758 areas with smaller saturated thickness see their groundwater last further into the future with a 759 policy. Under the flat tax scenario, the signs on the coefficients of lift are different between 760 farmers with positive net benefits in the market and negative net benefits from the flat tax, 761 largely because in the flat tax scenario farmers with larger lifts also had larger saturated 762 thickness and did not have their well dry up, while the benefactors of the market had larger lifts 763 which allocated them less water through the market, but allowed them to pump longer through 764 this reduced pumping and increased their gains. Another aspect that is different in the water 765 markets compared to the flat tax policy is that the water demand intercept, which is related to the 766 size of the marginal gains in a period, is negatively correlated with net benefits under the water 767 market but positively correlated with net benefits under the flat tax policy. This arises from the 768 relationship between the equilibrium allocations in the water market and the exhaustion of the 769 aquifer in relatively thin saturated areas. All the farmers whose net benefits increase from the 770 water market extend the life of their well to some degree compared to the baseline scenario but 771 the areas with smaller saturated thickness and smaller water demand intercepts extend the life 772 further into the future through lower water allocations in the water market in the earlier periods 773 and obtain larger gains, even if that benefit is inadvertent since the water market does not 774 explicitly value the life span of a well. This phenomenon also produces the signs on the 775 coefficient of Well dried up, as farmers that gain from the water market are primarily ones that 
776 have smaller allocations of water and extend the life of their well which produces a positive sign

777 on the coefficient for Well dried up. While farmers that do worse in the water market have larger

778 allocations of water and shorten the life span of their well which produces a negative sign on the

779 coefficient for Well dried up. Water markets allocate water permits to the areas with higher

780 current period marginal gains regardless of future period consequences. As a result the life of

781 some wells is shortened under a water market which drives the overall difference between the

782 gains from a simple flat tax and a water market with the identical total water quantities. To

783 separate the contrasting effects of 1) the gain from allocating to highly productive areas in the

784 current period through markets and 2) the loss from earlier exhaustion caused by allocating to

785 highly productive areas with a thin saturated thickness, let us consider the gains from a water

786 market after the first period of the simulation because this isolates the gain from reallocating

787 under the water market. Comparing the aggregate net benefit for the aquifer with the optimal flat

788 tax of $547 \%$ after year 1 in the simulation to the net benefit with the same total extraction in year

7891 but allocations using a water market, the aggregate net benefit under the water market after the

790 first period is approximately $0.35 \%$ greater than the net benefit from the flat tax scenario after

791 the first period. This relatively small gain in allocative efficiency shows that even a small

792 negative effect from earlier exhaustion of the most productive locations in an aquifer could, and

793 does, cause a larger decrease in net benefits than the gains from a more efficient distribution.

794 This suggests that there might be good reason to have restrictions on trading in areas close to

795 depletion or to include other mechanisms that consider the exhaustion of wells as a component of

796 policy: this is further supported by the findings from the LEMA water market that improves on

797 the simple pricing and quantity restriction policies. This might also be reason why currently

798 functioning water markets are typically restricted to small areas where the common pool 
assumption is reasonable (for example, in Australia and U.S.) or else feature complex trading and zoning rules that place additional restrictions on the markets. ${ }^{12}$ Further work in this area would be beneficial, similar to the work on depletion of surface water flows from groundwater pumping based on distance (Brozovic and Young 2014).

\section{Conclusion}

We assess the benefits of simple groundwater policies in a detailed spatial model of groundwater extraction that is applied to the Ogallala aquifer in Northwest Kansas. In an aquifer where the intensity of water demand is uneven across the aquifer and where each farmer faces different saturated thickness it is not obvious how these policies would perform or how much they would contribute to increasing the aquifer-wide net benefit. When these physical heterogeneities are present and the aquifer is depletable, we find that while simple pricing policies and quantity restrictions yield small increases the overall net benefits, on average, to farmers from water extracted for irrigation these policies may be counter-productive for many farmers. In Kansas the increase in net benefit is highly skewed towards the farmers that run out of water in the base (no policy) case and therefore cannot continue farming, while any form of management allows them to extend the life of their farm and realize profits further into the future. But the simple pricing and quantity policies that may extend the life of the aquifer for some may be very damaging to others. By instituting a static water market to aid in a more efficient distribution of groundwater in each period but without regard to future consequences, the overall discounted net benefit over the life of the aquifer decreased compared to the simple pricing policies. This may point to the need for more spatially or temporally targeted water markets with additional restrictions when implemented over a large heterogeneous area, which is seen in practice in some 
822 areas of the United States and Australia. The local area management by LEMAs in Kansas re-

823 inforce this finding as focused localized policies may be substantially more effective at

824 increasing benefits of farmers compared to other simple policies like a tax that is uniform over

825 space and/or time. This is also relevant to the simple water markets, as they enhance net benefits

826 much better in a localized setting than across larger sections of the aquifer.

827 While the average net benefit from management may be relatively small, there is large 828 heterogeneity in the distribution of gains across farmers and areas. Net benefits can easily 829 exceed $50 \%$ of discounted profits in areas of high water scarcity. Our results demonstrate the 830 need to focus policy on areas that run out of water because these are the areas with the largest 831 potential net benefits and are typically areas of concern for water managers, and show that the 832 distribution of gains is just as, if not more, important than the average gains across all farmers 833 when there are physical and demand heterogeneities. In our model when a well runs out of 834 groundwater the cost of no management, or no conservation, can be particularly high. This result 835 is similar to the one found in Koundouri and Christou (2006) who find that salt water intrusion 836 which destroys the ground water stock in Cyprus can reduce welfare significantly when there is 837 no backstop.

838 In all the simple pricing scenarios that we investigate the net benefit to the median farmer 839 is negative or close to zero. This suggests that these policies are unlikely to pass a popular vote 840 in Kansas. This emphasizes why local policies could be a more popular mechanism for 841 groundwater management, since these policies can be targeted to areas with potentially large 842 gains where the majority of farmers have positive net benefits such as in the Sheridan County 6 843 High Priority Area (SD-6 HPA) in Kansas. 
846

847 Adams B, Foster S S D (1992) Land-surface zoning for groundwater protection. Water and

848 Environment Journal 6(4):312-319.

849

850

851

852

853

854

855

856

857

858

859

860

861

862

863

864

865

866

867

\section{References}

Athanassoglou S, Sheriff G, Seigfried T, Tim Huh W (2012) Optimal mechanisms for

heterogeneous multi-cell aquifers. Environmental and Resource Economics 52(2):265-291

Bauer C (1997) Bringing water markets down to earth: The political economy of water rights in

Chile, 1976-95. World Development 25(5):639-656

Brennan D (2006) Water policy reform in Australia: lessons from the Victorian seasonal water market. The Australian Journal of Agricultural and Resource Economics 50:403-423

8

599 Brown T (2006) Trends in water market activity and price in the western United States. Water Resources Research 42, W09402, doi:10.1029/2005WR004180.

62 Brozović N, Sunding D, Zilberman D (2010) On the spatial nature of the groundwater pumping externality. Resource and Energy Economics 32:154-164

65 Brozović N, Young R (2014). Design and implementation of markets for groundwater pumping rights. In Water Markets for the 21st Century 283-303. Springer Netherlands. 
868 Burness H, Brill T (2001) The role for policy in common pool groundwater use, Resource and 869 Energy Economics 23:19-40

870

871 Cary J, Zilberman D (2002) A model of investment under uncertainty: Modern irrigation

872 technology and emerging markets in water. American Journal of Agricultural Economics

873 84(1):171-183

874

875 Colby B, Crandall K, Bush D (1993) Water right transactions: Market values and price 876 dispersion. Water Resources Research 29(6):1565-1572, doi:10.1029/93WR00186.

877

878 Didri C, Khanna M (2005) Irrigation technology adoption and gains from water trading under asymmetric 879 information. American Journal of Agricultural Economics 87(2):289-301

880

881 Gisser M, Sanchez D A (1980) Competition versus optimal control in groundwater 882 pumping. Water Resources Research 16(4):638-642

883

884 Gisser M (1983) Groundwater: Focusing on the real issue. The Journal of Political Economy 91 885 (6): 1001-1027

886

887 Gleeson, T., Wada, Y., Bierkens, M. F., \& van Beek, L. P. (2012). Water balance of global 888 aquifers revealed by groundwater footprint. Nature,488(7410), 197-200

889

890 Goemans C, Pritchett J (2014). Western water markets: Effectiveness and efficiency. In Water 891 Markets for the 21st Century 305-330. Springer Netherlands. 
893 Guilfoos T, Pape A, Khanna N, Salvage K, (2013) Groundwater management: The effect of 894 water flows on welfare gains. Ecological Economics 95:31-40

895

896 Hadjigeorgalis E. (2009) A Place for Water Markets: Performance and Challenges. Applied

897 Economic Perspectives and Policy 31(1):50-67

898

899 Hendricks N, Peterson J (2012) Fixed effects estimation of the intensive and extensive margins

900 of irrigation water demand. Journal of Agricultural and Resource Economics 37(1):1-19

901

902 Johnson CW (1982) Texas groundwater law: a survey and some proposals. Nat. Resources J.

$903 \quad 22: 1017-1030$

904

905 Jousma G, Roelofsen FJ (2004) Report number GP2004-1. International Groundwater Resources

906 Assessment Centre. October 2004

907

908 Koundouri P, Christou C (2006) Dynamic adaptation to resource scarcity and backstop 909 availability: theory and application to groundwater. The Australian Journal of Agricultural and 910 Resource Economics 50:227-245

911

912 Kuwayama, Y, Brozovic, N (2013) The regulation of a spatially heterogeneous externality:

913 Tradable groundwater permits to protect streams. Journal of Environmental Economics and 914 Management 66(2): 364-382. 
916 Mukherji A (2004) Groundwater markets in ganga-meghna-brahmaputra basin: Theory and

917 evidence. Economic and Political Weekly 39(31): 3514-3520

918

919 Mulligan K B, Brown C, Yang Y C E, Ahlfeld D P (2014). Assessing groundwater policy with

920 coupled economic groundwater hydrologic modeling. Water Resources Research 50(3): 2257-

9212275.

922

923 Muller N, Mendelsohn R (2009) Efficient pollution regulation: getting the prices right. The

924 American Economic Review:1714-1739

925

926 Murphy J, Dinar A, Howitt R, Rassenti S, Smith V (2000) The Design of “'Smart" Water Market

927 Institutions Using Laboratory Experiments. Environmental and Resource Economics 17(4):375-

$928 \quad 394$

929

930 Palazzo A, Brozović N (2014). The role of groundwater trading in spatial water 931 management. Agricultural Water Management 145:150-160

932

933 Qiu, J. (2010). China faces up to groundwater crisis. Nature, 466(7304), 308-308.

934

935 Savage J, Brozovic N (2011) Spatial externalities and strategic behavior in groundwater 936 pumping. Paper presented at The Inaugural AERE Summer Conference, Seattle, WA, 9-10 June 9372011

938 
939 Sekhri S (2011) Public provision and protection of natural resources: Groundwater irrigation in 940 rural India. American Economic Journal: Applied Economics 3(4):29-55.

941

942 Stavins, R N (1995) Transaction costs and tradeable permits. Journal of environmental

943 economics and management, 29(2):133-148

944

945 Suter J, Duke J, Messer K, Michael H (2012) Behavior in a spatially explicit groundwater

946 resource: Evidence from the lab. American Journal of Agricultural Economics 94(5):1094-1112

947

948 Thompson C L, Supalla R J, Martin D L, McMullen B P (2009) Evidence supporting cap and

949 trade as a groundwater policy option for reducing irrigation consumptive use. Journal of the

950 American Water Resources Association 45(6):1508-1518.

951

952 Tsur Y, Dinar A (1997) The relative efficiency and implementation costs of alternative methods

953 for pricing irrigation water. The World Bank Economic Review 11(2):243-262

954

955 Weinberg M (2002) Assessing a policy grab bag: Federal water policy reform. American Journal 956 of Agricultural Economics 84(3):541-556

957

958 Weinberg M, Kling C, Wilen J (1993) Water Markets and Water Quality. American Journal of 959 Agricultural Economics 75(2):278-291

960

961 Wheeler S, Schoengold K, Bjornlund H (Forthcoming) Lessons to be learned from groundwater 962 trading in Australia and The United States, in press 75(2):278-291 
Zimmerman W (1990) Finite hydraulic conductivity effects on optimal groundwater pumping rates. Water Resource Research 26(12):2861-2864

Table 1: Summary of Ogallala Aquifer Parameters

\begin{tabular}{|c|c|c|}
\hline Symbol & Description & Value \\
\hline$I$ & Number of farmers & 2,088 \\
\hline$N$ & Number of cells in aquifer & 8,457 \\
\hline $\mathrm{R}_{i}$ & $\begin{array}{l}\text { Average natural recharge of each cell } \\
\text { in aquifer (acre feet per year) }\end{array}$ & $\begin{array}{c}35.48(\max =75.99 \\
\min =26.67)\end{array}$ \\
\hline $\mathrm{A}_{i}$ & $\begin{array}{l}\text { Surface area of aquifer of each cell } \\
\text { (acres) }\end{array}$ & 625 \\
\hline $\mathrm{S}$ & Specific yield (unitless) & 0.17 \\
\hline $\mathrm{K}_{i}$ & $\begin{array}{l}\text { Average hydraulic conductivity for } \\
\text { each cell (feet/year) }\end{array}$ & $\begin{array}{l}23,393(\max =73,000 \\
\min =3,394)\end{array}$ \\
\hline $\mathrm{CA}_{0}$ & $\begin{array}{l}\text { Average cross sectional area of each } \\
\text { cell at time } 0 \text { (acres) }\end{array}$ & $6.33(\max =21.21 ; \min =0)$ \\
\hline $\mathrm{d}$ & $\begin{array}{l}\text { Distance between centroids of adjacent } \\
\text { cells (feet) }\end{array}$ & 5,217 \\
\hline $\mathrm{LS}_{i}$ & Average elevation of a cell (feet) & $\begin{array}{l}3,102(\max =4,024 ; \min = \\
2,104)\end{array}$ \\
\hline $\mathrm{g}_{i}$ & $\begin{array}{l}\text { Average farmer demand intercept (acre } \\
\text { feet) }\end{array}$ & $\begin{array}{c}178.84(\max =1,022.31 \\
\min =0.22)\end{array}$ \\
\hline $\mathrm{k}_{i}$ & $\begin{array}{l}\text { Average farmer demand slope (acre } \\
\text { feet) }\end{array}$ & $\begin{array}{c}-0.66(\max =-0.001 \\
\min =-3.17)\end{array}$ \\
\hline $\mathrm{C}_{1}^{\mathrm{a}}$ & $\begin{array}{l}\text { Cost increase of pumping from a one } \\
\text { foot change in height ( } \$ / \text { acre foot of } \\
\text { lift) }\end{array}$ & 0.1044 \\
\hline$\alpha$ & Return coefficient to well & 0.20 \\
\hline $\mathrm{r}$ & Rate of time preference & 0.03 \\
\hline $\mathrm{T}$ & Time period length (year) & 90 \\
\hline$\delta$ & $\begin{array}{l}\text { Minimum saturated thickness for a } \\
\text { farmer to pump water (feet) }\end{array}$ & 10 \\
\hline
\end{tabular}

Table 2: Water Demand Statistics 


\begin{tabular}{|lcc|}
\hline & Mean & Standard Dev. \\
\hline Applied Water per Acre (feet) & 1.1107 & 0.4501 \\
Cost of Pumping (dollars per acre foot) & 13.3620 & 6.5895 \\
Jan-April Precipitation (inches) & 3.5658 & 2.0579 \\
May-August Precipitation (inches) & 11.4602 & 4.8201 \\
May-August Evapotranspiration (inches) & 37.5238 & 6.0554 \\
\hline
\end{tabular}

Table 3: Water Demand Estimates

\begin{tabular}{|lcc|}
\hline & Dependent Var: Applied Water per Acre \\
Cost of Pumping (\$ acre foot) & $-0.00395^{* * *}(0.0014)$ \\
Jan-April Precipitation & 0.0041 & $(0.0063)$ \\
May-August Precipitation & -0.0039 & $(0.0029)$ \\
May-August Evapotranspiration & -0.0023 & $(0.0032)$ \\
\hline \hline Observations & 29,177 \\
$\mathrm{R}^{2}$ & \multicolumn{2}{c|}{0.4003} \\
Number of Groups & \multicolumn{2}{c|}{1473} \\
\hline
\end{tabular}

976

977

978

979

\section{Table 4: Results Summary Statistics}

Note: Standard errors are parentheses and coefficients on time fixed effects are not reported. Asterisk(*) denotes variables significant at $10 \%$.

\begin{tabular}{|c|c|c|c|c|c|c|}
\hline \multicolumn{7}{|c|}{ \% Gain in Discounted Farmer's Net Benefits } \\
\hline & $(1)$ & $(2)$ & $(3)$ & $(4)$ & $(5)$ & $(6)$ \\
& Flat Tax & Variable Tax & $\begin{array}{c}\text { Quantity } \\
\text { Restrictions } \\
(\mathrm{QR})\end{array}$ & $\begin{array}{c}\text { Water Market } \\
\text { with FT } \\
\text { Quantities }\end{array}$ & $\begin{array}{c}\text { Water Market } \\
\text { with VT } \\
\text { Quantities }\end{array}$ & $\begin{array}{c}\text { Water Market } \\
\text { with QR } \\
\text { Restrictions }\end{array}$ \\
\hline Total Gain & $1.02 \%$ & $1.06 \%$ & $0.00 \%$ & $0.99 \%$ & $0.99 \%$ & $0.11 \%$ \\
Min & $-100.00 \%$ & $-100.00 \%$ & $-1.99 \%$ & $-100.00 \%$ & $-100.00 \%$ & $-6.73 \%$ \\
Max & $720.73 \%$ & $722.33 \%$ & $9.44 \%$ & $7,071.90 \%$ & $189.79 \%$ & $5,469.07 \%$ \\
Average & $0.34 \%$ & $0.38 \%$ & $-0.01 \%$ & $63.86 \%$ & $0.09 \%$ & $10.75 \%$ \\
Median & $-0.23 \%$ & $-0.20 \%$ & $0.00 \%$ & $11.51 \%$ & $-0.51 \%$ & $0.00 \%$ \\
\hline
\end{tabular}

Table 5: LEMA SD-6 HPA Results

\begin{tabular}{|c|c|c|c|c|c|c|}
\hline & $\begin{array}{c}\text { Aquifer } \\
\text { wide Flat } \\
\text { Tax }\end{array}$ & $\begin{array}{c}\text { SD-6 HPA } \\
\text { Flat Tax } \\
\text { Quantity } \\
\text { Restriction }\end{array}$ & $\begin{array}{c}\text { Aquifer } \\
\text { Restriction } \\
\text { Ruantity } \\
\text { Rester }\end{array}$ & $\begin{array}{c}\text { SD-6 Water } \\
\text { FT } \\
\text { Quantities }\end{array}$ & $\begin{array}{c}\text { SD-6 Water } \\
\text { Quarket with } \\
\text { QR } \\
\text { Quantities }\end{array}$ \\
\hline Optimal Flat Tax Rate & $547 \%$ & $1362 \%$ & - & - & - & - \\
\hline Optimal Quantity & - & - & $98 \%$ & $32 \%$ & - & -
\end{tabular}




\begin{tabular}{|c|c|c|c|c|c|c|}
\hline Total Gain & $5.63 \%$ & $7.25 \%$ & $0.01 \%$ & $8.81 \%$ & $8.16 \%$ & $11.55 \%$ \\
Min & $-5.57 \%$ & $-32.01 \%$ & $0.00 \%$ & $-21.66 \%$ & $-41.76 \%$ & $-46.25 \%$ \\
Max & $26.88 \%$ & $15.54 \%$ & $0.00 \%$ & $25.67 \%$ & $26.54 \%$ & $25.57 \%$ \\
Average & $5.14 \%$ & $6.76 \%$ & $0.01 \%$ & $9.44 \%$ & $7.17 \%$ & $10.40 \%$ \\
Median & $4.77 \%$ & $7.84 \%$ & $0.00 \%$ & $13.75 \%$ & $10.37 \%$ & $14.37 \%$ \\
\hline
\end{tabular}

Note: The results here are the percent gains by the group of farmers in SD-6 HPA, under locally focused policies and aquifer wide policies.

\begin{tabular}{|c|c|c|c|c|}
\hline \multirow[b]{3}{*}{$\%$ Gains $>0$} & \multicolumn{4}{|c|}{ Dependent Var: \% Gain from Policy } \\
\hline & FT (1) & FT (2) & WMFT (3) & WMFT (4) \\
\hline & No & Yes & No & Yes \\
\hline Acreage irrigated & $7.61 \mathrm{E}-05$ & $5.65 \mathrm{E}-04$ & $3.95 \mathrm{E}-04 * * *$ & $3.37 \mathrm{E}-03^{*}$ \\
\hline Saturated thickness & $-6.44 \mathrm{E}-04 * *$ & $-8.74 \mathrm{E}-03 * * *$ & $-1.82 \mathrm{E}-03 * * *$ & $-7.23 \mathrm{E}-02 * * *$ \\
\hline Lift & $-4.75 \mathrm{E}-04 * *$ & $2.31 \mathrm{E}-03$ & 4.90E-04 & $2.05 \mathrm{E}-02 * *$ \\
\hline Hydraulic conductivity & $-3.60 \mathrm{E}-06$ & $2.02 \mathrm{E}-05$ & $7.06 \mathrm{E}-06$ & $1.36 \mathrm{E}-04$ \\
\hline Recharge & $5.35 \mathrm{E}-04$ & $1.78 \mathrm{E}-02$ & $-5.78 \mathrm{E}-03$ & $-1.48 \mathrm{E}-01 *$ \\
\hline Neighbor's irr. acres & $1.70 \mathrm{E}-05$ & $3.59 \mathrm{E}-05$ & $-4.98 \mathrm{E}-05$ & $-9.99 \mathrm{E}-04 * *$ \\
\hline Elevation & $1.49 \mathrm{E}-04$ & $-1.45 \mathrm{E}-04$ & $1.69 \mathrm{E}-03 * * *$ & $6.09 \mathrm{E}-03$ \\
\hline Water demand intercept & $1.12 \mathrm{E}-01 * * *$ & $2.24 \mathrm{E}-02$ & $1.15 \mathrm{E}-02$ & $-4.14 \mathrm{E}+00 * * *$ \\
\hline Well dried up & $-1.59 \mathrm{E}-02$ & $2.48 \mathrm{E}-02$ & $-3.50 \mathrm{E}-02 *$ & $1.29 \mathrm{E}+00 * * *$ \\
\hline Acreage irrigated sq. & $-3.72 \mathrm{E}-07 * * *$ & $-5.13 \mathrm{E}-07$ & $-9.20 \mathrm{E}-07 * * *$ & $-4.16 \mathrm{E}-07$ \\
\hline Saturated thickness sq. & $4.54 \mathrm{E}-06 * * *$ & $4.65 \mathrm{E}-05 * * *$ & $5.98 \mathrm{E}-06^{*}$ & $3.16 \mathrm{E}-04 * * *$ \\
\hline Lift sq. & $1.19 \mathrm{E}-07$ & $-4.03 \mathrm{E}-06$ & $-7.92 \mathrm{E}-06$ & $-1.43 \mathrm{E}-04 *$ \\
\hline Hydraulic cond. sq. & $1.55 \mathrm{E}-10$ & $-6.46 \mathrm{E}-10$ & $-2.56 \mathrm{E}-10$ & $-5.48 \mathrm{E}-09$ \\
\hline Recharge sq. & $-9.18 \mathrm{E}-06$ & $-2.29 \mathrm{E}-04$ & $1.95 \mathrm{E}-04 * * *$ & $2.10 \mathrm{E}-03 * *$ \\
\hline Neighbor's irr. acres sq. & $2.15 \mathrm{E}-11$ & $-1.85 \mathrm{E}-08$ & $1.66 \mathrm{E}-08$ & $3.53 \mathrm{E}-07 * *$ \\
\hline Elevation sq. & $-3.13 \mathrm{E}-08^{*}$ & $2.05 \mathrm{E}-08$ & $-2.40 \mathrm{E}-07 * * *$ & $-7.82 \mathrm{E}-07$ \\
\hline Observations & $1,1,537$ & 501 & 647 & 1,391 \\
\hline $\mathrm{R}^{2}$ & 0.2247 & 0.0875 & 0.1351 & 0.2194 \\
\hline
\end{tabular}

987 Asterisks $(*)$ double asterisks $(* *)$ and triple asterisks $(* * *)$ denote variables significant at $10 \%, 5 \%$, and $1 \%$, 988 respectively.

989

990

991

992

993 
Figure 1: Estimated Useful Lifetime for the High Plains Aquifer in Northwest Kansas Figure 2: 8,457 Cell Model of Northern Kansas, Ogallala Aquifer Figure 3: Total Groundwater Extraction Paths Figure 4: Total Discounted Net Benefit from Flat Tax Policy Figure 5: Distribution of Discounted Net Benefit Under Optimal Flat Tax Policy Figure 6: Quantity Restriction Figure 7: LEMA SD-6 HPA in Northwest Kansas Figure 8: Well Locations with Positive Gains from Flat Tax

\footnotetext{
${ }^{1}$ We do not calculate the first best policies due to computational limitations. There is a trade-off in adding a finer level of spatial detail and the ability to calculate a first best policy for the entire aquifer. Guilfoos et al. (2013) evaluate the welfare gains from groundwater management under a first best policy in an aquifer with substantially less spatial detail.

${ }^{2}$ When there is heterogeneity in the properties of the aquifer or the spacing of wells, the water price from a simple market may not be efficient. When the water rights from a thick saturated area where there are few neighbors are sold to an area with a thin saturated area and many neighbors there is likely to be a larger negative pumping externality on the area with many neighbors than the area with few neighbors, this would suggest that a water price for permits should vary with location. This is similar to the pollution permit literature where there are local concentration problems and benefits to ambient pollution standards or permits (Stavins 1995, Muller and Mendelsohn 2009). When the spatial element of the pumping cost externality is not priced into the water market it is unclear how much welfare is gained by instituting a market, though spatial externalities are priced into markets in Palazzo and Brozovic (2014) and Kuwayama and Brozovic (2013) that price interactions between surface water and groundwater.

${ }^{3}$ If banking 100 acre feet of water: First the $15 \%$ is reduced from Consumptive Use $(100 *(1-.15))=85$ acre feet. Then the additional $5 \%$ is reduced through a conservation reduction $(85(1-.05))=80.75$ acre feet.

${ }^{4}$ In this application we study an unconfined aquifer where this measure is specific yield. Storativity could be substituted for a confined and aquifer using the same model.
} 
${ }^{5}$ This is monitored by the Kansas Water Authority through metered pumps. There are a small number of cases where pumping exceeds the authorized limits and farmers are subject to fines or forfeiture of their water rights all together. Here we assume the limit is binding.

${ }^{6}$ We have also tried a tax that varies every period by assuming a simplified exponential functional form for the taxes, similar to Burness and Brill (2001), and find similar results.

${ }^{7}$ If the intercept is measured on a per acre basis, this shift in the intercept could be one measure that would be expected to vary closely with the productivity of the land over similar crops. Later in the paper we employ fixed effects that estimates different water demand intercepts on a per acre basis.

${ }^{8}$ During each year farmers extract water and water flows laterally between neighbors. Because the size of the cells is rather small in this simulation we allow water to flow laterally four times during one time period and convert the yearly hydrologic conductivity to units of feet per one quarter of a year. For example, for a cell with the average annual hydraulic conductivity of 10,000 , we transform $K=2,500$ acre feet per quarter of a year. The benefit of this is that is removes the likelihood that the dynamics of the model will be jumpy and devolve into a chaotic system, which is a remnant of the fact that we model this process in discrete time and not continuous time.

${ }^{9}$ Code for our model can be found at https://sites.google.com/site/toddguilfoos/ for replication.

${ }^{10}$ The model estimated is ActualHeight $2010_{n}=\beta^{*}$ PredictedHeight $2010_{n}+\varepsilon_{n}$, where $n$ is the number of cells in the aquifer. We find a high R-squared and a coefficient $\beta$ that is highly significant and equal to 1.003.

${ }^{11}$ The variable neighboring farms is defined as the eight cells surrounding a farmer and represents a summation of the total irrigated acreage in the eight surrounding cells.

${ }^{12}$ We thank an anonymous reviewer for pointing this out. 